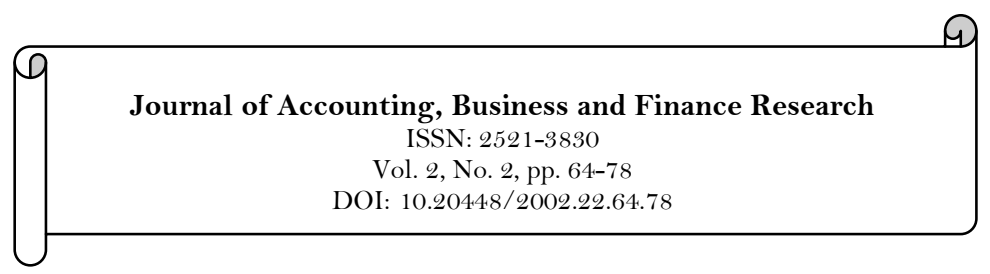

\title{
The Effect of Business Intelligence and Intellectuals Capital of Company Value Moderated by Management of Profit Riil
}

\author{
Susanti Widhiastuti's \\ Etty Murwaningsari ${ }^{2}$ \\ Sekar Mayangsari ${ }^{3}$ \\ $\mathbf{-}^{1,2,3}$ Trisakti University, Jakarta, Indonesia \\ 'Email:willy.arafah@hotmail.com
}

\begin{abstract}
The research purposes to analyze the influence of business intelligence and intellectual capital on firm value, and also the role of real earnings management as moderated variable. This research used annual report as secondary data. The number of beginning samples were 420 manufacturing firms. The final samples were 284 samples had a positive cash flow, because this study did not use samples with negative cash flow. This research uses moderated multiple regression and treat real earnings management as pure moderated variables. The results showed that business intelligence and intellectual capital had positive effects on firm value. Moreover, real earnings management significantly moderated the relationship between business intelligence, intellectual capital and firm value. The implication of the research showed that the company must give attention to business intelligence, intellectual capital and real earnings management. All independent variables can explain $86 \%$ of the variation in firms value.
\end{abstract}

\section{Introduction}

The era of globalization and the increasingly competitive level of companies has changed the business sector of the industry in managing the company. To face the level of competition, the management of the company can be done optimally either through internal or external. Internal

management not only maximizes the tangible resources, but also the intangible resources of intellectual capital, Secundo, Kong, Margherita, Elia, and Passiante (2010) and supported by business intelligence as a source to acquire and manage information (Pirttimaki \& Karjaluoto, 2006). Business intelligence is a useful system and information center to assist in decision-making processes. Information is obtained by collecting, consolidating, analyzing, and accessing data that enables users to make better business decisions. One measure of business intelligence is the cost of research and includes market research (market potential research, market trends, impression research, sales trends, business trends and market characteristic research). Mulyadi (2001), Gibson, Arnott, and Melbourne (2004), Yeoh, Koronios, and Gao (2008), Sartono (2012) and Imhoff (2003) explain the main reason for using business intelligence is to optimize business processes within a company with existing information systems to store data large daily transactions and humans have limited ability in analyzing huge data to produce information that can assist in decision making process. Ubiparipović and Durković (2011), Pirttimaki and Karjaluoto (2006) and Al-Shubiri (2012) also affirm that business intelligence is very helpful for managers and product managers in identifying different levels of customers and producing products or services that meet the needs of customers. But Davison and Birch (2001) argues otherwise that business intelligence has little effect on corporate improvement. Based on the explanation of the benefits of business intelligence, there are constraints on how to measure business intelligence. Therefore, in this study, business intelligence measurements are proxyed with all costs incurred to obtain sources of information to obtain data related to advertising costs, and costs for information technology because these three costs are the main sources and information managers that are very helpful to the company in terms of decision making quickly, precisely, and efficiently and this will have an impact on increasing the value of the company. Companies that have utilized the business intelligence system are PT. Sampoerna, Tbk PT. Gudang Garam, Tbk and PT. Coca Cola. This measurement of business intelligence as an update on this research is in addition to real earnings management as a moderating variable that weakens the influence of business intelligence and 
intellectual capital on firm value. In addition to business intelligence, other factors that affect the increase in corporate value is intellectual capital. Secundo et al. (2010), Afshari, Gadsden, and Habibi (2014), Son et al. (2012) and Jacub (2012) affirmed the importance of intellectual capital resources, whether for profit-oriented companies or nonprofit companies in the face of levels competition in the company. The result of his research stated that intellectual capital have positive effect to firm value but research result of Iranmahd, Moeinaddin, Shahmoradi, and Heyrani (2014), Sunarsih and Mendra (2012) shows that intellectual capital has negative effect. The gap underlies the need for further research because there are inconsistencies in the results of the study. In the management of intellectual capital in the company there is allegedly real earnings management that can weaken the influence of intellectual capital with the value of the company. This study uses real earnings management as a moderator of intellectual capital to firm value. (Roychowdhury, 2006), Cohen and Zarowin (2010) explained that earnings management through real activity is a management action that deviates from normal business practices undertaken with the primary goal of achieving profit targets.

In this study real earnings management is used as a moderation that weakens the influence of business intelligence and intellectual capital on firm value, due to various previous research results Roychowdhury (2006), Partami, Sinarwati, Darmawan, and SE (2015), Ustman (2016) and Vajriyanti, Widanaputra, and Putri (2015) earnings management affects firm value and in other studies (Sudibya \& Restuti, 2014), and Nuryaman (2015) show that intellectual capital affects firm value, but there are also reverse results in Iranmahd et al. (2014). This result raises allegations of other variables that can weaken the relationship between intellectual capital and firm value, and one of the variables that is suspected to affect is real profit management. Some earnings management studies (Cohen \& Zarowin, 2010; Cohens \& Paul, 2008; Gunny, 2005) explain that firms perform real earnings management ways in annual financial reporting through price discounts for increase temporary sales, enlarge production to lower the cost of production. To lower the level of earnings management companies must use all the resources capabilities possessed in the form of intellectual capital and supported by a powerful information technology system in the form of business intelligence, so the risk of activities that can reduce the value of the company can be minimized. Other factors that affect the value of the company is the size of the company, capital structure, growth that can control the value of the company. The basis for the use of control variables is based on the results of previous research, (Joshi, Jay, \& Arti, 2012), Sudarmadji and Sularto (2007), Vahid and Mohsen (2012) and Christiani (2010) environmental researchers. Based on the background of the problem, suggestions for further research and gap of previous research results that appear inconsistent results, the researchers want to revisit the problem and affirm that business intelligence, intellectual capital moderated by real earnings management has a major influence on the value of the company. Advanced research under the heading "The Influence of Business Intelligence and Intellectual Capital to Company Value with Real Profit Management As Moderating". Based on the background of the problem, then the research problems that can be formulated are 1) Does the business intelligence have a positive effect on the value of the company? 2) Does intellectual capital have a positive effect on company value? 3) Does real earnings management weaken the impact of business intelligence on corporate value? 4) Does real earnings management weaken the influence of intellectual capital on corporate value?

\section{Literature Review}

\subsection{Business Intelligence and Company Value}

Rubin and Rubin (2007) explained that with business intelligence a decision would be a data-driven decision on reports available to stakeholders and becoming more informative and impacting company performance more consistently and predictably. And supported by Research (Mulligan et al., 2000) and Vodapalli (2009) confirmed that with business intelligence can increase the value of the company. Based on the above explanation that a company if you want to have a high competitiveness compared with other similar companies, increase profits as much as possible with the cost as efficiently as possible and the main goal of the company is achieved that prosper the shareholders and other stakeholders achieved then it is better to apply the system well-managed business intelligence.

\subsection{Intellectual Capital and Corporate Value}

Research conducted by Mojtahedi et al. (2013) found that the relationship between intellectual capital and corporate financial performance in Malaysia (profitability, and sales growth) is positive and significant. The empirical findings show that proper management and reporting of intellectual capital assets will create added value for the organization. Another study conducted by Darabi et al. (2012) which found that intellectual capital has a positive and significant impact on earnings quality, the conclusion shows that intellectual capital has a positive role in financial practice and reporting. Ulum, Ghozali, and Purwanto (2008) also conducts research on the banking sector in Indonesia. The results also state that intellectual capital is statistically influential to firm performance and firm value.

\subsection{Real Profit Management and Corporate Value}

The role of managers as managers of the company will obtain more complete information about the condition of the company than the shareholders (owners), therefore the manager has an obligation to provide 
information about the development of the company during a certain period of time to the owner who can be done through the financial statements. With the financial statements submitted, the shareholders (owners) can know the financial condition to see the performance achieved and the value of the company, but the information submitted sometimes contain information asymmetry. Investors and creditors use earnings information as one of the information to see the company's performance and investment decisions. Gunny (2005), Trisnawati, Sasongko, and Puspitasari (2016) conducts research on real profit management (as independent variables) with firm value. The results of the study proved that management has done real profit majamen with varied patterns through cash flow, production costs and discretionary burden. In this study earnings management functions as a variable that moderate the influence of business intelligence and intellectual capital on the value of the company by using cash flow earnings management and production profit management.

\subsection{Control Variables}

In this research, there are 4 supporting factors as control variable that influence firm value, that is firm size, leverage (LEV), corporate performance (Tobin's Q) and Growth (GR). Selection of Size, LEV, Kin and GR as control variables are variables that can be controlled or made constant so that the influence of independent variables on dependents is not influenced by outside factors that are not examined (Sugiyono, 2011) because based on the results of previous research Mondal and Ghosh (2012); and Evadewi and Meiranto (2014), these variables can control and influence the value of the company. Control variables in Mondal and Ghosh (2012), in the banking sector using leverage as measured by total debt with total assets and Size as measured from natural $\log$ of assets. The result of the research stated that leverage has a significant negative effect to financial performance and firm value and Okolie (2014) using operational cash flow control variable, sales growth and leverage. Hansen and Juniarti (2014) adding control variables, namely firm size, growth and leverage. Evadewi and Meiranto (2014) and Sudarmadji and Sularto (2007). Adding leverage variables, sales growth, firm size and firm age as control variables. Selection of control variables in this study because of the inconsistency of previous research results, and adjusted also with the type and condition of the company in Indonesia, and other factors that directly affect the value of the company.

\subsection{Research Hypothesis}

\section{Hypothesis 1. Business Intelligence Affects Positively to Company Value}

Business intelligence can assist the decision-making process in the face of the level of competition in business units including in manufacturing companies. Data and information generated based on knowledge, competitive conditions, changing business needs to generate faster, precise and effective decisions for all parts of the company including the financial, accounting, sales and marketing sections. This opinion is reinforced by (Mulligan et al., 2000) and Vodapalli (2009) which shows that business intelligence applications can lower costs and increase sales. Implementation can be done through market research to obtain information data processed with information technology and re-communicate through advertisements within each company management in addition to creating value companies can see market opportunities, efficiency of time and cost, and the speed of information obtained. The same study was conducted by Pirttimaki and Karjaluoto (2006); Rubin and Rubin (2007). Gilad and Gilad (1985) also explained that the results of market research information in the form of competitor data, new product development, product innovation and supported by complete information technology is a form of real activity on business intelligence. Thus all organizations that have well-managed business intelligence activities have an impact on business information that is fast, precise and cost efficient so that company performance and corporate value can increase. Thus the first hypothesis is: H1. Business Intelligence has a positive effect on company value

\section{Hypothesis 2. Intellectual Capital Influence Positive to Company Value}

Based on the resource theory of intellectual capital companies is believed to increase the value of the company. Putra (2012) proves that intellectual capital has a positive and significant impact on the value of the company which is reflected in the stock price in the market. Intellectual capital that positively affects the value of the company shows that the company is able to manage its intellectual resources well which is believed to increase the market perception towards the value of the company and able to create added value and able to create competitiveness by doing innovation and creation. This confirms that intellectual capital plays a huge role in determining corporate value. The research of intellectual capital is also done by Randa and Solon (2012); Nuryaman (2015); Joshi et al. (2012) and Abdulmohammadi (2005) which show that intellectual capital has positive and significant effect on company value Based on the above explanation, hypothesis second is:

H2. Intellectual Capital positively affects the value of the company

\section{Hypothesis 3. Real Profit Management Weaken the Influence of Business Intelligence to Company} Value

A strong impetus to implement business intelligence is to see competitor's activities and market developments that can be done efficiently, quickly, and appropriately about business information for decisionmaking for management. This shows that business intelligence activities become an important tool for a 
company. Based on this basis to obtain information systems through business intelligence in the implementation there is information asymmetry from the role of business intelligence, because of the element of self-interest that can weaken the company in achieving the success of a business that can be done through through operational cash flow Cohens and Paul (2008) to conduct business intelligence as well as through earnings management through production. This opinion is reinforced by Shubiri (2013) who examines business intelligence at the industry sector company in Jordan. Shubiri (2013) study explains the importance of business intelligence, as one of the perspectives that affect performance, customer growth processes and their impact on finance, as well as Stanat et al. (1990), Stanat et al. (1999) research. The result of Ustman (2016) also proves that real profit management through operational cash flow also has a positive effect on company value. Based on these explanations, it can be asserted that real earnings management through operational cash flow that disrupts the level of investor valuation of the company's performance will weaken the business activities of the company through business intelligence and impact on the value of the company. Based on the above explanation, the third hypothesis is:

H3. Real earnings management weakens the impact of business intelligence on corporate value.

\section{Hypothesis 4. Real Profit Management Leverages Intellectual Capital Influence on Corporate Value}

High intellectual capital and quality can strengthen the company to be able to compete with other similar companies, with the creativity and innovation of the company can grow well and this will increase the profits of the company also affect the value of the company. Several previous studies on intellectual capital and firm value show a positive and significant impact on firm value judged by market value, Chen, Cheng, and Hwang (2005), Rubhyanti (2008), Nuryaman (2015), Sudibya and Restuti (2014). In contrast to Sunarsih and Mendra (2012), Iranmahd et al. (2014) studies show that intellectual capital is a negative influence on companies. In the implementation of the influence of intellectual capital on the value of the company sometimes arises the existence of earnings management that can weaken the value of the company. Roychowdhury (2006) study found consistent evidence that managers make earnings management through real operations to avoid annual reporting losses and there is evidence to suggest earnings management through real activity against inventory stocks. In supervision for the efficiency and effectiveness of the use of operational costs (Kamil, 2014) explains that the greater the management of real earnings the lower the value of the company. The results of the study Roychowdhury (2006), Ustman (2016), show real earnings management weaken firm value. Based on the explanation of intellectual capital and firm value shows that intellectual capital is positive and significant to firm value, and real earnings management negatively impacts firm value.

Based on the above explanation, the fourth hypothesis is:

H4. Real earnings management can weaken the influence of intellectual capital on firm value

\section{Research Methods}

This study uses secondary data. The research design was prepared to test the hypothesis by using multiple regression with pure moderation variables. Data using panel data (Ghozali, 2013), The population in his research is all manufacturing industry companies listed in Indonesia Stock Exchange (BEI) year 20132015. The group of manufacturing companies in the year 2013 numbered 136 companies, in 2014 amounted to 141 companies and in 2015 amounted to 143 companies so the total population is 420 companies. The technique of determining the number of samples in this study is purposive sampling (Sugiyono, 2011). The financial statements used in this study are financial reports that only have a positive cash flow. This relates to the use of the formula of real earnings management cash flow operations. For testing data using classical assumptions, Model test using $\mathrm{t}$ test and $\mathrm{F}$ test.

\subsection{Operational Definition}

\subsubsection{The Value of the Company}

Measurement of company value based on market value (Fernandez, 2015). In this study, the company valuation by me $\log$ the market value. Company Value $=\log$ (company stock price $\mathrm{x}$ number of shares outstanding)

\subsubsection{Business Intelligence}

Measurement of business intelligence on this research by modifying and developing from an explanation of the benefits gained and the costs incurred through business intelligence. Mulyadi (2001) the basis is that business intelligence is not a product, technology or methodology, but a business intelligence as a combination of products, technologies and methodologies to manage the information required by the management company in order to increase revenue and profit. The measure developed in this study to measure business intelligence is the sum of the research costs, advertising costs and information system costs incurred to obtain and manage information useful for management in making decisions that are done quickly, precisely and cost efficiently, and compared revenue that has been received, because the measure of success in previous researchers is the company's profits due to increased sales.

Based on these explanations business intelligence can be formulated as follows: 


\subsubsection{Intellectual Capital}

The measurement of intellectual capital refers to the measurements developed by Pulic (2000). These measurements are based on research by Vishnu and Gupta (2013), Ulum et al. (2008) and Nuryaman (2015). The intellectual capital in this study was proxied by VAICTM measured by the sum of value added of asset capital (VACE), Human Capital (VAHU) and structural capital (VASC)

The VAICTM calculation formulation is:

$$
\text { VAICTM = VACE + VAHC + VASC }
$$

Stage of VAICTM calculation formulation: is:

(1) Calculating VA is the difference between output and input

$$
\mathrm{VA}=\mathrm{OUT}-\mathrm{IN}
$$

Information

Output $($ OUT $)=$ Total sales and other revenue.

Input (IN) = Loads and amount of costs (other than personnel expenses).

(2) Calculating the Value Added Capital Employed (VACE) shows the contribution made by each unit of the $\mathrm{CA}$ to the value added organization

$$
\mathrm{VACE}=\mathrm{VA} / \mathrm{CE}
$$

Information:

Capital Employed (CE): Available funds (equity)

(3) Calculating Value Added Human Capital (VAHC) shows the contribution made by each rupiah invested in $\mathrm{HC}$ to the value added of the organization.

$$
\mathrm{VAHC}=\mathrm{VA} / \mathrm{HC}
$$

Information:

Human Capital (HC): Employee Charges

(4) Calculating the Value Added Structural Capital (VASC) measures the amount of Structural Capital required to produce 1 Rupuah of $\mathrm{VA}$.

$$
\begin{array}{r}
\mathrm{SC}=\mathrm{VA}-\mathrm{HC} . . \\
\mathrm{VASC}=\mathrm{SC} / \mathrm{VA}
\end{array}
$$

Information:

$\mathrm{SC}$ is the selsisih between value added (VA) and Human Capital (HC).

(4) Calculating the Value Added Intellectual Coefficient (VAICTM).

\subsubsection{Real Profit Management}

The measurement of real earnings management is based on measurements developed by Roychowdhury (2006) and Partami et al. (2015). Derived from the residual value of the estimation result of abnormal cash flow, abnormal production at firm $\mathrm{i}$ in year t. Measuring the abnormal value of each activity refers to the deviation between the actual activity value. In this study, real profit management measurements only use abnormal operating cash flows and production costs. Abnormal discretionary costs are not used because of the possibility of multicollinearity with the intelligence business. This condition occurs because the abnormal measurement formula of discretion cost includes the cost (advertising cost) which is also the measure of business intelligence.

\subsubsection{Abnormal Operating Cash Flow}

This earnings management can be done through sales by way of discounting and impacting the impairment of corporate value.

The linkage between intellectual capital with intelligence on real cash flow earnings management is thought to be earnings management performed by intellectual resources and information systems related to business intelligence on the company's operating cash flow. Earnings management through operational cash flow, Roychowdhury (2006), Partami et al. (2015) are:

CFO_it $/ \mathrm{A}_{-}(\mathrm{it}-1)=\alpha \_0+\alpha \_1 * 1 / \mathrm{A} \_(\mathrm{it}-1)+\alpha \_2 * \mathrm{~S} \_$it $/ \mathrm{A} \_(\mathrm{it}-1)+\alpha \_3 * \llbracket \Delta \mathrm{S} \rrbracket \_$it $/ \mathrm{A} \_(\text {it-1 })+\varepsilon_{-}($ it) ... (4)

Where:

$\mathrm{CFO}$ it = Operating cash flow of company $\mathrm{i}$ in year $\mathrm{t}$.

A it-1 $=$ Total assets of company $\mathrm{i}$ in year $\mathrm{t}-1$.

$\mathrm{S}$ it $=$ Sales of company i in year $\mathrm{t}$.

$\square \mathrm{S}$ it $=$ Sales of company $\mathrm{i}$ in year $\mathrm{t}$ minus i company sales in year $\mathrm{i}-1, \square \mathrm{S}$ it $=$ Sit $-\mathrm{S}$ it -1 .

$\square \mathrm{o}, \square 1, \square 2, \square 3=$ Constants

$\square$ it = Error residual company $\mathrm{i}$ in year $\mathrm{t}$.

MLR CFO = Residual CFO 


\subsubsection{Abnormal Production Cost}

Abnormal production costs are made through earnings management through iproduction. This profit management is done by excessive production in order to reduce the cost of goods sold. The estimate of deviations from the cost of production is the value of real production earnings management.

Abnormal production costs, Roychowdhury (2006), Partami et al. (2015) are:

『PROD』_it $/ \mathrm{A}_{-}(\mathrm{it}-1)=\alpha \_0+\alpha \_1 * 1 / \mathrm{A} \_(\mathrm{it}-1)+\alpha \_2 * \mathrm{~S} \_$it $/ \mathrm{A} \_$(it-1) $+\alpha \_3 * \llbracket \Delta \mathrm{S} \rrbracket \quad$ it $/ \mathrm{A} \_(\text {it- } 1)$ $+\alpha \_4 *$ * $\llbracket \Delta \mathrm{S} \rrbracket \_\left(\text {it-1) / A_ (it-1) }+\varepsilon_{-} \text {it }\right.$

Where:

PROD it = Company cost $\mathrm{i}$ in year $\mathrm{t}$, is COGS it $+\square \mathrm{INF}$ it (Cost of Goods Sold plus inventory change)

$\square \mathrm{S}$ it-1 = Sales of company i in year $\mathrm{t}-1$ minus sales in year $\mathrm{t}-2$, $\square \mathrm{S}$ it $=\mathrm{S}$ it $-1-\mathrm{S}$ it -2 .

MLR prod $=$ Residual Prod it

\subsubsection{Control Variables}

Some previous studies include control variables to determine the effect of independent variables on firm value. Okolie (2014), Hansen and Juniarti (2014) in his study used sales growth control variables, firm size, and leverage to firm value as well as Komalasari, Purwanto, and Suharyanto (2014).

In this research, there are four factors of control variable that influence firm value and incorporated into regression model, ie firm size, leverage (LEV), company performance (Tobin's -Q) and growth (GR), with the following measurement:

\subsubsection{Company Size}

The size of the firm in this study uses natural $\log (\mathrm{Ln})$ of total company assets, Iranmahd et al. (2014) calculated by the formula:

Size $=$ Log of total assets of company $\mathrm{i}$ in year $\mathrm{t}$

\subsubsection{Leverage}

Leverage in this research using Debt Equity Ratio (DER),

Iranmahd et al. (2014), which is calculated by the formula:

$\mathrm{LEV}=($ Total Debt $) /($ Total Asset of Company i in year $\mathrm{t}) \ldots(7)$

\subsubsection{Company Performance}

Company performance is measured using Tobins'Q. Lindenberg and Ross (1981) and Sudiyatno and Puspitasari (2010):

Total Assets

$$
\text { Tobin's q }=\text { Market Value }+ \text { Debt }
$$

\subsubsection{Sales Growth}

Company growth is measured using sales growth, Vahid and Mohsen (2012) by:

Growth Penj $=\left(\llbracket\right.$ Sales on th】_ $t-\llbracket$ Sales year $\left.\_(t-1)\right) /$ Sales year $\_(t-1) \ldots(9)$

\subsection{Model Test}

The model test in this research uses $\mathrm{F}$ test by confirming goodness of fit at R2 value and F-Count value is statistically significant at $10 \%$ level. And t test by using a one-sided test, with the criteria of a hypothesis accepted if the significance level is less than $10 \%$.

\subsection{Data Analysis Techniques}

The research model consists of the main model and the alternative model. Business intelligence and intellectual capital variables (as independent variables), real profit management (as moderating variables) and firm size, leverage, firm performance and sales growth (as control variables) as well as interaction between independent variables and dependent variables).

\subsubsection{Main Research Model}

The research model consists of the first major model without moderation and the second model with moderation. In this study real earnings management as a pure moderation variable is a variable that directly interact with independent variables and not as independent variables. This model is as one of the alternative classical validation models proposed by Saunders (1956), Coheni and Patricia (1975). Sharma (1986) explains that pure moderation is a variable that moderates the relationship between independent variables and dependent variables in which pure moderation variables interact with independent variables without being independent variables.

Based on the above explanation the research model can be made: 


\subsubsection{Main Research Model without Moderation Variables \\ 3.4.1.2. Moderation Main Research Model}

\section{Results and Research Analysis}

\subsection{Research result}

\subsubsection{Descriptive statistics}

The study population amounted to 420 companies obtained from $2013-2015$,. The research data used are companies that have positive cash flow as much as 299 of that number which complete financial statements 284. Based on the sample descriptive statisiknya seen in Table 4.1.

Table-4.1. Statistik Descriptive.

\begin{tabular}{l|l|l|l|l|l}
\hline & $\mathrm{N}$ & Minimum & Maximum & Mean & Std. Deviation \\
\hline BI & 284 & 0.00 & 0.24 & 0.02 & 0.04 \\
\hline IC & 284 & -8.87 & 9.23 & 2.29 & 1.93 \\
\hline NP & 284 & 22.43 & 33.71 & 27.63 & 2.17 \\
\hline SIZE & 284 & 25.30 & 32.64 & 28.40 & 1.54 \\
\hline KEV & 284 & 0.04 & 7.15 & 0.55 & 0.56 \\
\hline PERT & 284 & 0.10 & 18.64 & 1.75 & 2.22 \\
\hline MLCFO & 284 & -0.60 & 1.99 & 0.08 & 0.25 \\
\hline MLPROD & 284 & 0.00 & 2.59 & 0.14 & 0.27 \\
\hline Valid N (listwise) & 284 & 0.04 & 15.74 & 1.07 & 1.09 \\
\hline
\end{tabular}

\subsubsection{Classic Assumption Test Results}

The classical assumption testing process includes: normality test, multicolinearity test, heteroskedity test, and autocorrelation test. The results of the classic assumption test and model test can be seen as follows:

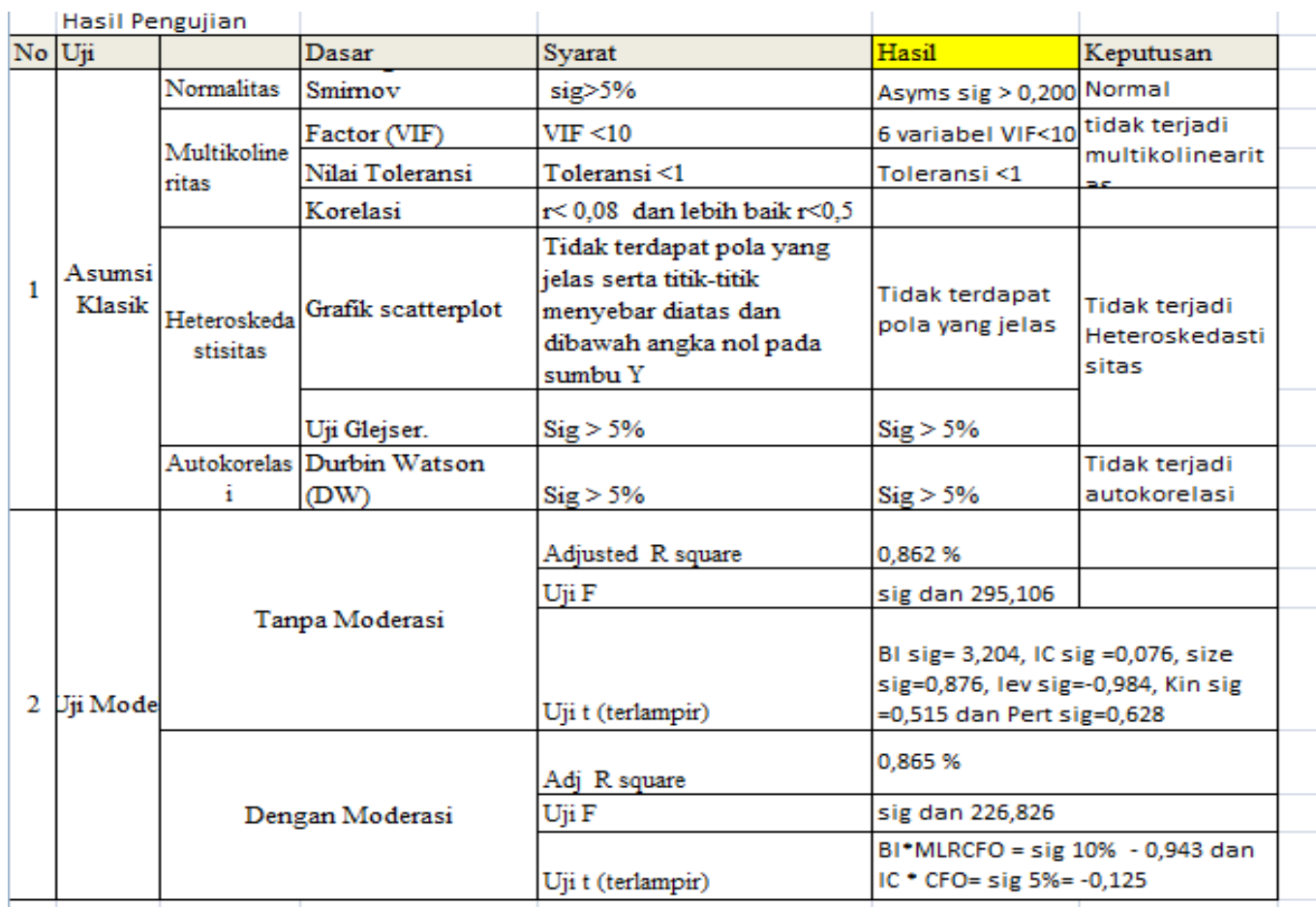

Based on these tests the research data is normally distributed, there is no multicolinearity, heteroskedasitas and autocorrelation between variables.

\subsubsection{Hypothesis Test Results}

This research uses main model and alternative model. The main model uses moderate earnings management real cash flow and alternative models using real production earnings management. The main model uses two steps namely the first main model is to know the effect before there is moderation and the 
second main model is to know the magnitude of influence after the moderation of cash flow real earnings management.

\subsubsection{Hypothesis Test Results without Moderation}

Based on the results of the output spss known that the hypothesis of business intelligence and intellectual capital is supported, it means that business intelligence and intellectual capital affect the value of the company. The output of main model spss before moderation can be seen in Table 4.2 as follows:

Table-4.2. Regression Results Without Moderation Variables (H1 and H2).

\begin{tabular}{l|l|l|l|l|l}
\hline Variabel & $\begin{array}{l}\text { Ekspek } \\
\text { tasi }\end{array}$ & $\begin{array}{l}\text { Unstandardized } \\
\text { Coefficients }\end{array}$ & t statistics & Sig & $\begin{array}{l}\text { Conclusion } \\
\text { Hipotesis }\end{array}$ \\
\hline (Constant) & & 2.132 & 2.397 & .009 & \\
\hline BI & + & 3.204 & 2.318 & $.011^{* * *}$ & $\mathrm{H}_{1}$ didukung \\
\hline IC & + & .076 & 2.220 & $.014^{* * *}$ & $\mathrm{H}_{2}$ didukung \\
\hline SIZE & + & .876 & 27.535 & $.000^{* * *}$ & \\
\hline LEV & - & -.984 & -10.108 & $.000^{* *}$ & \\
\hline KIN & + & .515 & 19.187 & $.000^{* * *}$ & \\
\hline PERT & + & .628 & 2.921 & $.002^{* * *}$ & \\
\hline R Square & & .865 & F-Statistic & 295.106 & \\
\hline Adjusted R ${ }^{2}$ & & .862 & Prob (F-Stat) & $.000^{b}$ & \\
\hline
\end{tabular}

a. Predictors: (Constant), BI, IC, SIZE, LEV, KIN, PERT.

b.Dependent Variable: NP.

**** Sig. pada level $1 \%$.

Based on the output of SPSS in Table 4.8, the regression equation that can be made in the formula (10) is: Company Value $=2,132+3,204 \mathrm{BI}+0.076 \mathrm{IC}+0.876 \mathrm{Siz}-0.984 \mathrm{Lev}+0,515 \mathrm{Kin}+0,862$ PERT.

Regression results without moderation for testing of $\mathrm{H}_{1}$ and $\mathrm{H} 2$ can be explained as follows:

\section{Hypothesis Test 1}

The first hypothesis states that business intelligence positively affects the value of the company. Based on $t$ test shows that business intelligence proved to have a positive effect on company value. which is shown on the scale of regression coefficient 3,204 and statistically significant equal to 0,011 so it can be concluded that business intelligence have positive effect to company value.

The results indicate that business intelligence as a combination of products, technology and methodology to manage information is needed as a strategy of the company so that business process can run smoothly and have high competitiveness done by building information technology for business interests. With the results of the test, the first hypothesis is stated supported.

\section{Hypothesis Test 2}

The second hypothesis states that intellectual capital has a positive effect on firm value. Based on the test results show that intellectual capital proved to have a positive influence on the value of the company. which is shown on the regression coefficient scale of 0.076 and is statistically significant at 0.014 so it can be concluded that business intelligence positively affects the value of the company.

These results indicate that intellectual capital as the main capital of the company to have a high competitiveness to increase the value of the company can be done by improving the quality of resources to be creative, innovate with the expertise owned and supported by assets owned. With the human resources, physical resources and resources of business management relations going well and this can give trust also to stakeholders, new investors, relationships and other stakeholders, this has an impact on increasing the company's clout and company value. With the test results, then the second hypothesis is stated supported.

\section{F Test for Hypotheses 1 and 2}

Based on Table 4.2 above shows that the $\mathrm{F}$ test value of 295.10 with a significance value of $0.000<0.05$ indicates that business intelligence, intellectual capital and control variables, ie firm size, leverage, performance, corporate growth have a positive and significant effect together equal to firm value.

The adjusted value of $\mathrm{R} 2$ at is obtained at 0.862 . This means that $86.2 \%$ of the company's value can be predicted from business intelligence variables, intellectual capital and control variables, ie firm size, leverage, performance, company growth during the period of 2013-2015, while the remaining $13.8 \%$ is affected by other variables that are not examined such as working capital and corporate liquidity.

\subsubsection{Hypothesis Test Result with Moderation (H3 and H4)}

The result of moderation test can be seen in Table 4.3 as follows: 
Table-4.3. Regression Result with Moderation.

\begin{tabular}{|c|c|c|c|c|c|}
\hline Variabel & Ekspektasi & $\begin{array}{l}\text { Unstandardized } \\
\text { Coefficients }\end{array}$ & t statistics & Signifikansi & Kesimpulan \\
\hline (Constant) & & 2.614 & 2.913 & .002 & \\
\hline $\mathrm{BI}$ & + & 3.056 & 2.228 & $.014^{* * * *}$ & H1 didukung \\
\hline $\mathrm{IC}$ & + & .066 & 1.950 & $.026^{* *}$ & H2 didukung \\
\hline BI*MLRCFO & - & -.943 & -1.438 & $\left..076^{*}\right)$ & $\mathrm{H}_{3}$ didukung \\
\hline IC*MLRCFO & - & -.125 & -1.716 & $\left..044^{* *}\right)$ & $\mathrm{H}_{4}$ didukung \\
\hline SIZE & + & .860 & 26.864 & $.000^{* * * *}$ & \\
\hline LEV & - & -.992 & -10.191 & $.000^{* * * *}$ & \\
\hline KIN & + & .504 & 18.754 & $.000^{* * * *}$ & \\
\hline PERT & + & .642 & 3.016 & $.002 * * *$ & \\
\hline R Square & & .868 & F-Statistic & 226.826 & \\
\hline Adjusted $\mathrm{R}^{2}$ & & .865 & Prob ( F-Stat) & $.000^{b}$ & \\
\hline
\end{tabular}
follows:

Based on the SPSS output, the regression equation that has been made in the above formula (10) is as

$\mathrm{NP}=2,614+3,056 \mathrm{BI}+0.066 \mathrm{IC}-0.943(\mathrm{BI} * \mathrm{MLR}-\mathrm{CFO})-0.125(\mathrm{IC} * \mathrm{MLR}-\mathrm{CFO})+0.860$ Size -0.992 Lev $+0,504$ Kin $+.0,642$ Pert.

\section{Hypothesis Testing 3}

The third hypothesis states that real cash flow earnings management weakens the influence of business intelligence on firm value.

Based on Table 4.3. and regression equation is shown regression coefficient scale in earnings cash flow management that moderate business intelligence and corporate value equal to - 0,943 and statistically significant at level $10 \%$ that is equal to 0,076 meaning that higher company do earnings management with cash flow hence company value progressively down and conversely if earnings management with cash flow is smaller then the value of the company is increasing. Based on the explanation it can be concluded that real cash flow earnings management weaken the influence of business intelligence on the value of the company. Based on the test results, then the fourth hypothesis (H3) is declared supported.

\section{Hypothesis Testing 4}

The fourth hypothesis states that real earnings management of cash flow weakens the influence of intellectual capital on firm value. Based on the test results show that real cash flow management is proven to weaken the influence of intellectual capital on the value of the company. Based on Table 4.3. and regression equation is shown regression coefficient amount in real cash flow management that moderate intellectual capital and company value equal to -0.125 and statistically significant at level $5 \%$ that is equal to 0,044 which means higher company do earnings management with cash flow hence company value progressively down and conversely if earnings management with cash flow is smaller then the value of the company is increasing.

Based on the explanation, it can be concluded that the real earnings management of cash flow weaken the influence of intellectual capital on the value of the company, thus the company in managing should pay attention to the intellectual resources possessed to the maximum that can be done by giving bonuses and performance allowances for the achievers so that earnings management reduced. Based on the test results, then the fourth hypothesis $\left(\mathrm{H}_{4}\right)$ is declared supported.

\section{F Test for Hypotheses 3 and 4}

Based on Table 4.3 above shows that the $F$ test value of 226.82 with a significance value of $0.000<0.05$ indicates that business intelligence, moderation of business intelligence and earnings management real cash flow, intellectual capital and intellectual moderation with real cash flow earnings management and control variables, ie firm size, leverage, performance, corporate growth have a positive and significant effect together on the value of the company.

The adjusted value of $\mathrm{R} 2$ square on is obtained at 0.865 . This represents an $86.5 \%$ predictable corporate value of business intelligence variables, moderation of business intelligence and real earnings management of cash flow, intellectual capital and intellectual capital moderation with real cash flow earnings management and control variables, ie firm size, leverage, performance, the growth of company-owned companies during the period 2013-2015, while the remaining 13.5\% influenced by other variables that are not examined such as working capital and the level of corporate liquidity. 


\subsubsection{Sensitivity Test}

The main model difference with the alternative model lies in hypotheses 3 and 4 namely the moderation of real profit management operational cash flows into real-production earnings management. In this alternative test the test is only performed on the third and fourth hypotheses because the interaction of business intelligence and intellectual capital with real earnings management occurs only in the third and fourth hypotheses.

Based on the output of SPSS obtained results that can be seen in Table 4.4 as follows:

\begin{tabular}{|c|c|c|c|c|}
\hline Variabel & $\begin{array}{l}\text { Unstandardized } \\
\text { Coefficients }\end{array}$ & t statistics & Signifikansi & Kesimpulan \\
\hline (Constant) & 2.138 & 2.417 & .008 & \\
\hline $\mathrm{BI}$ & 2.504 & 1.778 & $.038^{* * *}$ & H1 didukung \\
\hline $\mathrm{IC}$ & .072 & 2.112 & $.018^{* *}$ & H2 didukung \\
\hline BI*MLRPROD & -2.443 & -1.310 & $\left..096^{*}\right)$ & $\mathrm{H}_{3}$ didukung \\
\hline IC*MLRPROD & -.032 & -1.300 & $\left..098^{*}\right)$ & $\mathrm{H}_{4}$ didukung \\
\hline SIZE & .877 & 27.702 & $.000^{* * * *}$ & \\
\hline LEV & -.980 & -10.118 & $.000^{* * * *}$ & \\
\hline KIN & .514 & 19.292 & $.000^{* * * *}$ & \\
\hline PERT & .613 & 2.867 & $.002^{* * * *}$ & \\
\hline R Square & .867 & & & \\
\hline Adjusted $\mathrm{R}^{2}$ & .863 & & & \\
\hline Prob (F-stat) & $\begin{array}{l}224.595 \\
0.000\end{array}$ & & & \\
\hline
\end{tabular}

Based on the regression equation that has been made in the above formula (11), the value of the regression equation is:

Company Value $=2,138+2,504$ BI +0.072 IC - 2,443 (BI * MLR-Prod) - 0,032 (IC * MLR-Prod) + 0.877 Size - 0,980 Lev + 0,514 Kin + 0,613Pert.

\section{Hypothesis Testing 3}

A third hypothesis with an alternative test states that real production earnings management weakens the influence of business intelligence on firm value. Based on the test results show that the real profit management of production proven to weaken the influence of business intelligence on the value of the company. Based on Table 4.4 and regression equation shown regression coefficient amount on real production earnings management that moderate business intelligence and corporate value equal to -2.443 and statistically significant at level $10 \%$ that is equal to 0.096 which means higher company do earnings management with production hence firm value down and vice versa if real earnings management with production is smaller then the value of the company is increasing. Based on the explanation it can be concluded that real production earnings management weakens the influence of business intelligence on the value of the company. Based on the test results, then the third hypothesis (H3) alternative model is declared supported.

\section{Hypothesis Testing 4}

The fourth hypothesis states that real production earnings management weakens the influence of intellectual capital on firm value. Based on the test results show that the real profit management of production proven to weaken the influence of intellectual capital on the value of the company. Based on Table 4.4 and from the regression equation shows the regression coefficient on real production earnings management that moderate intellectual capital and corporate value of -0.032 and statistically significant at the level of $10 \%$ that is equal to 0.098 which means that the higher the company performs profit management through production then the value of the company the more down and vice versa if earnings management through production the smaller the value of the company is increasing. Based on the explanation can be concluded that real production earnings management weaken the influence of intellectual capital on the value of the company. Based on the test results, then the fourth hypothesis (H4) is declared supported.

\subsection{Modeling Model Comparison of Main and Alternative Models}

This comparison is made against hypotheses 3 and 4 because of the difference in existing real cash flow earnings management that can moderate business intelligence and intellectual capital with production earnings management. Comparison can be seen in the table as follows: 
Table-4.5. Comparison of the Influence of Business Intelligence with the Value of a Moderated Company - Real Profit Management (Main Model with Alternative Model).

\begin{tabular}{l|l|l|l|l|l}
\hline Variabel & Unstd. Coeff. $\beta$ & $\mathrm{t}$ & Sig. & Adj R Square & Keterangan \\
\hline BI * MLR-CFO & -0.943 & -1.438 & $\left.0.076^{* *}\right)$ & 0,865 & Moderasi BI-CFO \\
\hline BI * MLR-Prod & $-2,443$ & -1.310 & $\left.0.096^{* *}\right)$ & 0,863 & Moderasi BI-Prod \\
\hline *) signifikansi di level 5\% **) signifikansi di level 10\%. \\
Sumber: data diolah berdasarkan hasil sPSs.
\end{tabular}

Based on Table 4.5 the amount of real earnings management performed on business intelligence, through real earnings management on cash flow and earnings management on production, can be explained that both have an effect on company value. The magnitude of the effect to earnings management on the real-earnings management of prod is greater than through the real cash earnings management of the firm's value of $-2,443$ and -0.943 and the significant negative effect at a significant level of $10 \%$ to firm value means higher profit management will cause the decline in company value. It shows that production earnings management is more the effect of opportunity than cash flow earnings management (CFO) on the relationship between business intelligence (BI) to the value of the company.

While the comparison of intellectual capital influence on firm value moderated real earnings management can be seen in Table 4.6 as follows:

Table-4.6. Comparison of Intellectual Capital Influence on Corporate Value Moderated Real Profit Management (main and alternative models).

\begin{tabular}{l|l|l|l|l|l}
\hline Variabel & Unstd. Coeff. $\boldsymbol{\beta}$ & t & Sig. & Adj R Square & Ket \\
\hline IC * MLR-CFO & -0.125 & -1.716 & $\left.0.0448^{*}\right)$ & 0,865 & Moderasi IC-CFO \\
\hline IC * MLR-Prod & -0.032 & -1.300 & $\left.0.098^{* *}\right)$ & 0,863 & Moderasi IC -Prod \\
\hline $\begin{array}{l}\text { *) signifikansi di level 5\% **) signifikansi di level 10\%. } \\
\text { Sumber: data diolah berdasarkan output SPSS. }\end{array}$
\end{tabular}

Based on Table 4.6 above, real profit management amounts done to intellectual capital either through real earnings management to cash flow and earnings management real to production, can be explained that both have an effect on to decrease company value. The magnitude of the effect of the action of earnings management through cash flow is greater than through the production of the value of the company and the difference is big enough that is -0.125 significantly at the level of $5 \%$ and -0.032 with significant at $10 \%$ level and significant negative effect on firm value, the high earnings management performed by intellectual capital will cause a decline in the value of the company. It shows that earnings management is mostly done through cash flow compared to earnings management through production that influence to company.

\subsection{Discussion on Test Results of Main Hypotheses}

\subsubsection{Results of Hypothesis Testing without Moderation Variables}

The results of testing the first hypothesis states that business intelligence proved to have a positive effect on the value of the company with a coefficient of 3.204 against the value of the company. This proves that companies should use business intelligence by using information technology that can integrate data to manage their business. Business intelligence is the combination of research costs, information technology, advertising. Research is used to obtain information data collected with information technology and communicate back to interested parties through advertising. The combination of these three components proved to increase the value of the company. Pirttimaki and Karjaluoto (2006), Sundjaja and Inge (2003) explained that the company's business intelligence can research the market potential, market trends, impression research, sales trends, business trends and market characteristic research, as a tool to connect consumers, marketing variables and the environment to obtain information about products, prices, promotions, distribution, competition, technology, economic conditions, politics, social change and government regulations.

Through information systems, investors can find out more extensive and complex information about the development of stock prices in circulation. Gibson et al. (2004) and Yeoh et al. (2008) explains that business intelligence plays a role in searching, exploring and analyzing information from business data. Increasing corporate value from the use of strong business intelligence systems is also supported by control variables (firm size, leverage, performance and growth) that play a role in improving company value.

\subsubsection{Results of Second Hypothesis Testing}

Results of testing the second hypothesis states that intellectual capital has positive and significant influence with coefficient of 0.076 to firm value. These results prove that the maximum utilization of intellectual capital can be a key driver for companies that want to win the competition and prosper the shareholders as the main goal of the company. These findings support the research of Sudibya and Restuti (2014). Joshi et al. (2012), Mondal and Ghosh (2012), Chen et al. (2005) and Vishnu and Gupta (2013) show that intellectual capital has a positive relationship with financial performance and firm value. Intellectual capital encompasses all knowledge of employees, organizations, and their ability to create added value and lead to sustainable competitive advantage and impact on the increase in corporate value. 


\subsubsection{Third Hypothesis Testing Results}

The result of the third hypothesis testing states that the real cash flow earnings management is proven to significantly weaken the influence of business intelligence on corporate value with coefficient of -0.943. Based on these results prove that the use of real earnings management through cash flow can reduce the value of the company.

Lipsitz (2012) research, explains that business intelligence can be measured based on the costs incurred to acquire, manage and analyze data in order to obtain the information used as the basis for business decision making. But real earnings management has a negative effect on firm value.

Ubiparipović and Durković (2011) study, Pirttimaki and Karjaluoto (2006) and Al-Shubiri (2012) also assert that business intelligence is helpful to managers and product managers if properly managed, meaning that if there is management use of management elements profits also result in lower corporate value. Based on the results of research has been proven that earnings management weaken the influence of business intelligence on the value of the company in manufacturing industry companies Tbk on BEI period 2013-2015.

\subsubsection{Hypothesis Testing Results Fourth}

The results of the fourth hypothesis testing states that the real cash flow management earnings proved to weaken significantly the influence of intellectual capital on corporate value with a coefficient of -0.125. Based on these results prove that the use of real earnings management practices will reduce the influence of intellectual capital on the value of the company.

The study was also supported by Partami et al. (2015), Kamil (2014) and Ustman (2016) who gave the same conclusion. Based on the results of a proven study that earnings management weaken the influence of intellectual capital on the value of the company

The results of this study support agency theory which states that the agency conflict can be caused by lack of information and this leads to agency costs that can cause a decline in company performance that affect the value of the company.

\subsubsection{Hypothesis Testing Results Fourth}

The results of the fourth hypothesis testing states that the real cash flow management earnings proved to weaken significantly the influence of intellectual capital on corporate value with a coefficient of -0.125. Based on these results prove that the use of real earnings management practices will reduce the influence of intellectual capital on the value of the company.

The study was also supported by Partami et al. (2015), Kamil (2014) and Ustman (2016) who gave the same conclusion. Based on the results of a proven study that earnings management weaken the influence of intellectual capital on the value of the company

The results of this study support agency theory which states that the agency conflict can be caused by lack of information and this leads to agency costs that can cause a decline in company performance that affect the value of the company.

\section{Conclude, Implications and Recommendations for Administrative Research \\ 5.1. Conclusion}

Based on the results of data analysis for the main model of research, got some conclusions as follows:

1. Business intelligence has a significant positive effect on the company's value of 3.056 and the control variable (except leverage) has a positive and significant influence simultaneously or alone on the value of the company. These results confirm the Williams, Umberson, Powers, Liu, and Needham (2006), Pirttimaki and Karjaluoto (2006), Sundjaja and Inge (2003).

2. Intellectual capital has a significant positive effect on the company's value of 0.066 and the control variable has positive and significant influence jointly or separately (except leverage) to the company value. The results confirm the research Jacub (2012), Sudibya and Restuti (2014).

3. Moderation real earnings management cash flow weakens the influence of business intelligence and intellectual capital on the value of the company. This shows the need for increased supervision of corporate management, especially in obtaining information relating to business intelligence so that earnings management can be reduced because it proves that earnings management can reduce the value of the company. These results confirm the study of Graham (2005) and Williams et al. (2006), Pirttimaki and Karjaluoto (2006).

4. Moderation real earnings management cash flow weakens the influence of intellectual capital on the value of the company. This shows the need for increased control of corporate resources, especially intangible resources owned by the company so that earnings management can be reduced because it proves that earnings management can reduce the value of the company. These results confirm the research of Partami et al. (2015).

5. Variable control firm size, performance, company growth have positive and significant influence individually or jointly to company value but for leverage have negative effect to company value.

Based on this conclusion can be explained that the contribution of the influence of independent variables, control variables and moderation variables to the value of the company is reflected in adjusted $\mathrm{R}$ square of 
$86.5 \%$ while the remaining adjusted $\mathrm{R}$ square of $13.5 \%$ influenced by un-researched variables such as liquidity, solvency, profitability and working capital generated by the company. The influence factor of adjusted $\mathrm{R}$ square is high because it only uses positive cash flow and accuracy of research model related to business intelligence variable and intellectual capital as variables that influence to firm value. Besides, it is supported by control variables based on previous research results have an effect on company value, so the control variable in this research also strengthens the result of previous research. These results confirm the study of Graham (2005), Kamil (2014), (Partami et al., 2015).

As for the alternative models of conclusions that can be taken is as follows:

1. Moderation of real production earnings management weakens the influence of business intelligence on firm value. These results confirm the study of Graham (2005) and Kamil (2014).

2. Moderation of real earnings management of production weakens the influence of intellectual capital on firm value. These results confirm (Partami et al., 2015), Kamil (2014).

Based on the above conclusion that business intelligence and intellectual capital greatly affect the value of the company. This confirms that with business intelligence and the quality of corporate resources in the form of intellectual capital owned as a business management information center has been run well so that all company decisions can be controlled and done quickly, precisely and efficiently and real earnings management can decrease.

The success of a company depends on developing resources in helping companies capture opportunities and neutralizing threats done to the fullest and supported by an adequate role of information technology will create a competitive advantage. Resource-based theory explains that competitive advantage will be achieved if resources must have superior capabilities and exceed competitors.

\subsection{The Implications of Theory and Managerial Implications}

\subsubsection{Theory Implication}

1. For academics, the results of business intelligence research, intellectual capital and moderation of real earnings management to the value of the company provide a new model in the measurement of variables that affect the value of the company. The research by combining several independent variables (business intelligence and intellectual capital) and moderation variables (real earnings management) includes the update in this research so that it can be a literature reference for further research.

2. The results of the study are useful to provide empirical evidence about factors that may affect the value of the company.

\subsubsection{Managerial Implications}

1. For the company, the results of this study indicate that the company should always take into account the cost of business intelligence to increase the value of the company because based on research results show that the cost of business intelligence can increase the value of the company. With business intelligence and the quality of human resources owned all the information available in the data bank can be run well so that earnings management can be minimized.

2. In addition to business intelligence the company should also pay attention to intellectual capital as a resource to increase the value of the company. For industrial companies, services and good professions that still make earnings management to limit the use of earnings management by disclosing in the financial statements on various transactions based cash flow and production.

\subsubsection{Limitations of Research}

Besides the research findings that have been obtained, of course, this study has several limitations:

1. Using real profit management that only includes corporate entities that have positive operational cash flow

2. In processing data encountered a number of outlier data so that the number of samples is reduced. This condition affects the generalization of the research.

5.2.4. Advanced Research Recommendations

As for suggestions that can be given in connection with the limitation of research that has been done, further research is expected to further refine this research on:

1. Add some theories and literature as well as the latest research results related to the variables studied such as business risk

2. Using research samples in different time periods

3. Using company performance control variables as independent variables that play a role in influencing the value of the company.

\section{References}

Abdulmohammadi, M. J. (2005). Intellectual capital disclosure and market capitalization. Journal of Intellectual Capital, 6(3), 397-416.

Afshari, H. H., Gadsden, S. A., \& Habibi, S. R. (2014). Robust fault diagnosis of an electro-hydrostatic actuator using the Novel dynamic second-order SVSF and IMM strategy. International Journal of Fluid Power, 15(3), 181-196. 
Al-Shubiri, F. N. (2012). Measuring the impact of intelijen bisnison performance: An empirical study. Jordan: Al Zaytoonah University Of Jordan, Faculty Of Economics And Administrative Sciences.

Chen, M. C., Cheng, S. J., \& Hwang, Y. (2005). An empirical investigation of the relationship between intellectual capital and firms market value and financial performance. Journal of Intellectual Capital, 6(2), 159-176.

Christiani, S. D. (2010). Comparative analysis of financial performance and stock performance before and after seasoned equity offerings in manufacturing companies on the IDX. Thesis, UNUD Master of Management Program.

Cohen, D. A., \& Zarowin, P. (2010). Accrual-based and real earnings management activities around seasoned equity offerings. Journal of Accounting and Economics, 50(1), 2-19.

Coheni, J., \& Patricia, C. (1975). Applied multiple regression/ correlation analysis for the behavioral sciences. Hillsdale, New Jersey: Lawrence Erlbaum Associates.

Cohens, D. A., \& Paul, Z. (2008). Accrual-based and real earnings management activities around seasoned equity offerings. Stern School of Business, New York University.

Darabi, A., Rozema, L. A., Mahler, D. H., Hayat, A., Soudagar, Y., \& Steinberg, A. M. (2012). Violation of Heisenberg's measurement-disturbance relationship by weak measurements. Physical Review Letters, 109(10), 100404.

Davison, K. K., \& Birch, L. L. (2001). Childhood overweight: A contextual model and recommendations for future research. Obesity Reviews, 2(3), 159-171.

Evadewi, R., \& Meiranto, W. (2014). Pengaruh pengungkapan corporate social responsibility terhadap earnings management: A political cost perspective. Diponegoro Journal of Accounting, 3(2), 948-959.

Fernandez, P. (2015). Valuing companies by cash flow discounting: Ten methods andnine theories. Journal Emerald Managerial Finance, 33(11), 853-876.

Ghozali, I. (2013). Multivariate analysis application with the IBM SPSS 21 program (7th ed.). Semarang: Diponegoro University Publisher.

Gibson, M., Arnott, D., \& Melbourne, A. (2004). Evaluating the intangible benefits of Intelijen Bisnis: Review \& research agenda. Paper presented at the Proceedings of the 2004 Ifip International Conference on Decision Support Systems (Dss2004): Decision Support in an Uncertain and Complex World.

Gilad, B., \& Gilad, T. (1985). A systems approach to Intelijen Bisnis. Business Horizons, 28(5), 65-70.

Graham, C. (2005). The economics of happiness. World Economics, 6(3), 41-55.

Gunny, K. (2005). What are the consequences of real earnings management. . Working Paper. University of Colorado.

Hansen, V., \& Juniarti. (2014). The effect of family control, size, sales growth and leverage on company profitability and value in the trade, services and investment sectors. Businnes Accounting Review, 2(1).

Imhoff, E. A. J. (2003). Accounting quality, auditing and corporate governance. Accounting Horizons, 17, 117-128.

Iranmahd, M., Moeinaddin, M., Shahmoradi, N., \& Heyrani, F. (2014). The effect of intellectual capital on cost of finance and firm value. International Journal of Academic Research in Accounting, Finance and Management Sciences, 4(2), 1-8.

Jacub, J. O. S. (2012). The effect of intellectual capital and its disclosure on firm value (Empirical Study of Pharmaceutical Companies on the IDX). Accounting Student Scientific Journal, 1(4), 96-100.

Joshi, N. A., Jay, D., \& Arti, T. (2012). Valuing companies by discounted cash flows. Ahmedabad, Gujarat, India: Institute of Management \& Research.

Kamil, F. (2014). The influence of earnings management on firm value with corporate governance mechanisms as moderating variables. Telkomuniversity.ac.id.

Komalasari, R. I., Purwanto, P., \& Suharyanto, S. (2014). Green building assessment based on energy efficiency and conservation (EEC) category at pascasarjana B building diponegoro University-Semarang. American Journal of Energy Research, 2(2), 42-46.

Lindenberg, E. B., \& Ross, S. A. (1981). Tobin's q ratio and industrial organization. Journal of Business, 1-32.

Lipsitz, J. W. (2012). The total economic impact of oracle business intelligence applications. Forrester Research, Magazine, $1(2), 45-48$

Mojtahedi, M., Pisco, A. O., Brock, A., Zhou, J., Moor, A., Jackson, D., \& Huang, S. (2013). Non-darwinian dynamics in therapy-induced cancer drug resistance. Nature Communications, 4(2467).

Mondal, A., \& Ghosh, S. K. (2012). Intellectual capital and financial performance of Indian banks. Journal of Intellectual Capital, 13(4), 515-530.

Mulligan, K., Grunfeld, C., Tai, V. W., Algren, H., Pang, M., Chernoff, D. N., \& Schambelan, M. (2000). Hyperlipidemia and insulin resistance are induced by protease inhibitors independent of changes in body composition in patients with HIV infection. Journal of Acquired Immune Deficiency Syndromes, 23(1), 35-43.

Mulyadi. (2001). Third edition accounting system. Jakarta: Salemba Empat.

Nuryaman, N. (2015). The influence of intellectual capital on the firm's value with the financial performance as intervening cariable. Procedia-Social and Behavioral Sciences, 211, 292-298.

Okolie, A., O. (2014). Audit tenure, auditor independence and accrual-based Eaenings management of quoted companies in Nigeria. European Journal of Accounting Auditing and Finance Research, 2(2), 63-90.

Partami, N. L. N., Sinarwati, N. K., Darmawan, N. A. S., \& SE, A. (2015). The effect of real earnings management on firm value with corporate governance as a moderating variable (Empirical Study of Manufacturing Companies Listed on the Indonesia Stock Exchange). JIMAT (Accounting Student Scientific Journal) Undiksha, 3(1).

Pirttimaki, V. L., \& Karjaluoto, A. (2006). Measurement Of intelijen bisnis in a finnish telecommunications Company. Electronic Journal of Knowledge Management, 4(1), 83-90.

Pulic, A. (2000). Intellectual capital: Navigating the new business landscape. London: Macmillan Pres Ltd.

Putra. (2012). Malaysia, optimization of spray drying process parameters of Piper betle L.(Sirih) leaves extract coated with maltodextrin. Journal of Chemical and Pharmaceutical Research, 1833-1841.

Randa, S., \& Solon, S. A. (2012). Effect of intellectual capital on firm value (Empirical study on manufacturing companies listed on the Indonesia Stock Exchange). Journal of Management and Accounting Information Systems, 1O(1), $24-47$. 
Roychowdhury, S. (2006). Earnings management through real activities manipulation. Journal of Accounting and Economics, 42(3), 335-370.

Rubhyanti, R. (2008). The relationship between intellectual capital and market value and financial performance. KOMPAK, $1(1), 55-61$

Rubin, E., \& Rubin, A. (2007). The impact of business intelligence systems on stock return volatility. Jurnal Business Intelligence (BI). University of British Columbia.

Sartono, A. (2012). Financial management, theory and applications. Yogyakarta: Publisher BPFE.

Saunders, D. R. (1956). Moderator variables in prediction. Educational and Psychological Measurement, 16(2), $209-222$.

Secundo, G., Kong, E., Margherita, A., Elia, G., \& Passiante, G. (2010). Intangible assets in higher education and research: Mission, performance or both? Journal of Intellectual capital.

Sharma, K. D. (1986). Runoff behaviour of water harvesting microcatchments. Agricultural Water Management, 11(2), 137144.

Shubiri, F. N. (2013). Measuring the imapct of business intellegence on performance: An empirical study. Polish Journal of Management Studies. Czestochowa Technical University, Department of Management(1), 162-173.

Son, D. I., Kwon, B. W., Park, D. H., Seo, W.-S., Yi, Y., Angadi, B., . . . Choi, W. K. (2012). Emissive ZnO-graphene quantum dots for white-light-emitting diodes. Nature Nanotechnology, 7(7), 465.

Stanat, S. C., Jacobson, M. A., Berger, T. G., Fikrig, S., Becherer, P., Moohr, J. W., \& Biron, K. K. (1990). Acyclovirresistant varicella zoster virus infection after chronic oral acyclovir therapy in patients with the acquired immunodeficiency syndrome (AIDS). Annals of Internal Medicine, 112(3), 187-191.

Stanat, S. C., Talarico, C. L., Burnette, T. C., Miller, W. H., Smith, S. L., Davis, M. G., \& Biron, K. K. (1999). Acyclovir is phosphorylated by the human cytomegalovirus UL97 protein. Antimicrobial Agents and Chemotherapy, 43(8), 19411946.

Sudarmadji, A., \& Sularto, L. (2007). Effect of company size, profitability, leverage, and type of company ownership on the area of voluntary disclosure of annual financial statements. Paper presented at the COMPLETE Proceedings.

Sudibya, D. C. N. A., \& Restuti, M. M. D. (2014). The effect of intellectual capital on firm value with financial performance as an intervening variable. Benefit: Journal of Management and Business, 18(1), 14-29.

Sudiyatno, B., \& Puspitasari. (2010). Tobin's q and Altman z-score as company performance measurement indicators. Accounting Study, 2(19), 9-21.

Sugiyono. (2011). Qualitative quantitative research method. Bandung: Alfabeta.

Sunarsih, N. M., \& Mendra, N. P. (2012). The effect of intellectual capital on corporate values with financial performance as intervening variables in companies listed on the Indonesia stock exchange. Aakuntansi National Symposium - XV.

Sundjaja, R., \& Inge, B. (2003). Financial management. Book one (4th ed.). Jakarta: Cross Media Literata.

Trisnawati, W., Sasongko, N., \& Puspitasari, N. (2016). Practice of real earnings management on JII and LQ45 index, Indonesia stock exchange. The 3rd University Research Colloquium.

Ubiparipović, B., \& Durković, E. (2011). Application of business intelligence in the banking industry. Management Information System, 6(4), 23-30.

Ulum, I., Ghozali, I., \& Purwanto, A. (2008). Intellectual capital performance of the banking sector in Indonesia. Journal of Accounting and Finance, $10(2), 77-84$.

Ustman, U. (2016). Analysis of the principle of musharaka and mudharabah profit sharing in the independent Islamic bank Pamekasan branch. Assets: Journal of Accounting and Investment, 1(1), 1-15.

Vahid, T. K., \& Mohsen, A. K. (2012). Working capital management and corporate performance: Evidence from Iranian companies. Procedia-Social and Behavioral Sciences, 62, 113-118.

Vajriyanti, E., Widanaputra, A. A. G. P., \& Putri, I. G. A. M. (2015). The effect of real profit management on company value with good corporate governance as a moderating variable. XVIII Accounting National Symposium, USU Medan.

Vishnu, S., \& Gupta, V. K. (2013). Intellectual capital and performance of performance of pharmaceutical firm in India.

Vodapalli, N. K. (2009). Critical success factors of BI implementation. IT University of Copehagen, 11(2), 140-157.

Williams, K., Umberson, D., Powers, D. A., Liu, H., \& Needham, B. (2006). You make me sick: Marital quality and health over the life course. Journal of Health and Social Behavior, 47(1), 1-16.

Yeoh, W., Koronios, A., \& Gao, J. (2008). Managing the implementation of Intelijen Bisnis systems: A critical success factors framework. International Journal of Enterprise Information Systems, 4(3), 79-94. 